\title{
NIETZSCHE E A QUESTÃO DA SUBLIMAÇÃO
}

\author{
Nietzsche and the sublimation question
}

\author{
Rogério Miranda de Almeida
}

Doutor em Filosofia pela Universidade de Metz, UM, França e em Teologia pela Université de Strasbourg II, US II, França, Professor do Programa de Pós-Graduação em Filosofia da PUCPR, Curitiba, PR - Brasil, e-mail: r.mirandaalmeida@gmail.com

\section{Resumo}

O objetivo deste texto é analisar a noção de sublimação em algumas obras de Nietzsche e, mais do que isto, mostrar que esta questão se encontra já nos seus primeiros escritos, aqueles que eu denomino pela expressão: "os escritos trágicos". Tanto em Nietzsche quanto em Freud, a sublimação se manifesta como um processo que, aparentemente, nada tem a ver com a sexualidade mas que, em última instância, encontra sua explicação na força das pulsões sexuais. Em Nietzsche, porém, além de uma sublimação da sexualidade, existe uma sublimação das pulsões de destruição, ou de morte. É sobre este último ponto que recai a ênfase destas reflexões.

Palavras-chave: Sublimação; Pulsões; Crueldade; Construção-destruição; Vontade de potência.

\section{Abstract}

This text aims at analyzing the notion of sublimation in some Nietzsche's works. More than that, however, it wants to show that this question can already be found at the very beginning of his production, which I designate by the expression: the "tragic writings". In Nietzsche as well as in Freud, the sublimation 
manifests itself as a process that, apparently, has nothing to do with sexuality. Nonetheless, its last reason is to be found in the force of the sexual drives. Moreover, besides a sexual sublimation, there exists, in Nietzsche, a destructive or death drives sublimation. Therefore, emphasis is place upon this last point.

Keywords: Sublimation; Drives; Cruelty; Constructiondestruction; Will to power.

\section{Introdução}

Sabe-se hoje, a partir dos recortes de datação operados pela edição Colli-Montinari sobre a obra de Nietzsche, que a expressão "vontade de potência" aparece, pela primeira vez, num fragmento póstumo de fim 1876verão 1877. ${ }^{1}$ Nas obras publicadas pelo autor, iremos encontrar esta mesma expressão somente em 1883, em Assim falou Zaratustra. ${ }^{2}$ Resta, contudo, que embora a expressão como tal só tenha vindo a público no terceiro e último período produtivo do filósofo, a problemática das forças e das relações de forças é aquela que realmente caracteriza, permeando-os, pontilhando-os e atravessando-os de maneira radical, todo o pensamento e toda a escrita do solitário de Sils-Maria. Os esquemas, de um modo geral, costumam ser subjetivos e arbitrários, sobretudo quando se tenta aplicá-los a uma obra tão dispersa e "contraditória" como o é aquela de Nietzsche, cuja escrita, ou cujo texto, se desenrola através de incessantes rupturas, retomadas, revalorações, reinterpretações, releituras e repetições. Mas pelo fato mesmo de o texto nietzschiano per-fazer-se através de uma dinâmica iterativa que, paradoxalmente, cria um novo texto, é possível seguir, nas suas grandes linhas, as principais tendências e os principais temas que recorrem no seio desta descontinuidade e re-inscrição de valores.

1 KSA 8, p. 425. Retenha-se ainda que todas as palavras em itálicos nas citações que eu fizer da obra de Nietzsche se encontram como tais no original, exceto quando se tratar de palavras estrangeiras ou quando houver menção explícita da minha parte.

2 Cf. Dos mil e um alvos (Primeira Parte); Da superação de si; Da redenção (Segunda Parte). 
Assim, poderíamos dizer, esquematicamente, que os primeiros escritos, que coincidem com o início de suas atividades professorais na Universidade de Basiléia (1869), são marcados pelas análises em torno da tragédia e da cultura gregas. Dentre esses textos sobressaem: $O$ nascimento da tragédia (1872), O Estado grego (1872), A justa em Homero (1872), A filosofia na época trágica dos gregos (1873), O drama musical grego, Sócrates e a tragédia e A visão dionisíaca do mundo, todos de 1870. Mas dentro deste mesmo primeiro período já se verifica uma inflexão de perspectiva que se exprime nas quatro Considerações extemporâneas (1873 -1876), de sorte que, tomados conjuntamente, os textos desta primeira fase têm por temas a arte e a cultura, a metafísica e a ciência, a moral e a religião, a psicologia e a linguagem. Todavia, é a problemática da estética e da cultura em geral que domina aquilo que eu designo pela expressão "os escritos trágicos", enquanto as Considerações extemporâneas irão deslocar o acento para a questão da civilização europeia e, em particular, da civilização alemã do século XIX. ${ }^{3}$ No período de transição, se opera uma revaloração na obra nietzschiana com a publicação dos três volumes que hoje compõem Humano, demasiado humano. Nestes três livros, que foram publicados separadamente: Humano, demasiado humano (1878), Miscelânea de opiniões e sentenças (1879), O andarilho e sua sombra (1880), é evidente a ênfase que recai sobre a moral de tipo utilitária e sobre a tradição hedonística que se deixa mais ou menos resumir pela fórmula: "evitar a dor e procurar o prazer". Deve-se, no entanto, ressaltar que estes escritos encerram mais paradoxos e ambiguidades que uma primeira leitura poderia levar a imaginar.

O terceiro e último período que, sob certos aspectos, já começa com Aurora (1881), retomará o tema da estética que, juntamente com o da cultura, caracterizava os "escritos trágicos". Mas é também nesta última fase, que se estenderá até o último ano da vida produtiva do filósofo (1888), que Nietzsche se revelará um mestre consumado na arte de analisar, auscultar, dissecar e diagnosticar a dinâmica das forças e das relações de forças que estão à base dos diferentes valores. Neste último período, portanto, que inclui, além

3 Convém notar a distinção que efetua Nietzsche nesses escritos, e no Nascimento da tragédia em particular, entre os termos Kultur e Zivilisation. O primeiro designa o conjunto das produções culturais e materiais de uma determinada época, de um determinado povo ou de uma sociedade. Quando, porém, o autor emprega a palavra Zivilisation, ou Civilisation, ele quer significar o requinte excessivo e decadente de uma Kultur, ou Cultur. Todavia, no capítulo 18 de O nascimento da tragédia, ele se serve da expressão alexandrinischen Cultur (civilização alexandrina) para justamente criticar a decadência do mundo moderno europeu que, na sua perspectiva, teve origem no modelo socrático do homem teórico. 
de Aurora, A gaia ciência, Assim falou Zaratustra, Para além de bem e mal, Genealogia da moral, O caso Wagner, Crepúsculo dos ídolos, O Anticristo, Ecce Homo, Nietzsche contra Wagner e os fragmentos póstumos, retornam aqueles temas e aquelas intuições que despontaram e se elaboraram desde os primeiríssimos textos. Contudo, estes mesmos temas e estas mesmas intuições serão revaloradas, reinterpretadas, transformadas e explicitadas na perspectiva do conceito fundamental da vontade de potência e das relações de forças que a determinam e são, por sua vez, por ela determinadas.

A vontade de potência é ambígua na medida em que ela se manifesta como vontade de expansão, de incorporação, de apropriação, de construção, mas também, e por isso mesmo, de aniquilamento, de destruição e - não menos importante ainda - de autodestruição. Esta vontade se encontra também, como deixei pressupor no início destas reflexões, nos "escritos trágicos", porquanto a civilização grega se edificou, segundo Nietzsche, sobre um embasamento de crueldade, de destruição, de sofrimento, de angústia e, consequentemente, de volúpia e gozo. Na concepção nietzschiana, não somente a civilização grega, mas toda civilização já é um monumento, uma expressão ou um sintoma de como a força e a energia que emanam das pulsões de destruição foram desviadas, elevadas, enobrecidas, espiritualizadas ou, numa palavra, sublimadas. Resta, portanto, analisar em que medida a sublimação das pulsões, tal como Nietzsche a intuiu e desenvolveu, diz respeito não somente a uma sublimação das pulsões sexuais, mas também, e talvez principalmente, das pulsões de agressão ou de destruição.

\section{Da sublimação em Nietzsche e em Freud}

Convém primeiramente notar que o adjetivo "sublime" evoca, como todos sabem, tudo aquilo que é fino, leve, refinado, elevado, espiritual, e que o substantivo "sublimação" é utilizado em química para designar a passagem de uma substância do estado sólido diretamente para o estado gasoso. Por analogia, Freud introduziu este termo em psicanálise para significar as ações humanas que, embora não tendo uma relação direta com a sexualidade, encontram sua última explicação na força da pulsão sexual. Há, portanto, sublimação quando a energia libídica é desviada para um outro alvo, cujas expressões principais são a atividade artística e a investigação intelectual. Este último sentido já se achava presente não só nos primeiros textos de Nietzsche, mas também naqueles que marcarão a segunda e a terceira fase de sua vida 
produtiva. Todavia, antes mesmo que Nietzsche e Freud dessem à palavra "sublimação" o significado pelo qual ela se tornaria mais conhecida, constatase a sua existência na literatura alemã da Idade Média através de uma adaptação do verbo latino sublimare. Ela já se encontrava igualmente em autores tão diversos quanto Goethe, Novalis e Schopenhauer. Goethe, por exemplo, adverte que não se devem trazer para o palco sentimentos e ações tais como são experienciados na natureza. Estes fenômenos, conclui o poeta, devem ser "elaborados, preparados, sublimados". ${ }^{4}$ Em Blütenstaub, escreve Novalis: "Assim como o mundo é, de certo modo, um depósito de natureza humana, assim também o mundo dos deuses é dele a sublimação. Eles se produzem uno acto" (NOVALIS, 1955, § 96).

Nas suas avaliações sobre as relações que se verificam entre Nietzsche e Freud quanto à noção de sublimação, os intérpretes se dividem entre um extremo e outro. Para Walter Kaufmann, Nietzsche simplesmente antecipou o uso que desta palavra faria Freud, enquanto Ofelia Schutte vê tãosomente uma semelhança superficial entre as teorias desenvolvidas pelos dois autores. Schutte declara, não totalmente sem razão, que para Nietzsche "a sublimação da energia sexual não é senão uma das diversas manifestações do processo criativo da Selbstüberwindung, subjacente a todas as formas de vida" (SCHUTTE, 1984, p. 207). A Selbstüberwindung (superação de si) deve ser compreendida, na perspectiva nietzschiana, não como um alvo determinado a ser alcançado, mas como um processo que não conhece nem começo nem fim, porquanto ele não cessa de recomeçar, de se renovar e de se afirmar a partir e através da pluralidade de forças e, consequentemente, de valores e interpretações. Ora, a ambiguidade fundamental da civilização, que pressupõe a renúncia à satisfação das pulsões, consiste precisamente em que se é continuamente levado a mudar de fantasmas e, assim, a torná-los mais "espirituais", mais "nobres", mais "finos", mais "elevados", mais "sublimes". De sorte que a sublimação é simultaneamente impedimento e passagem para o gozo, ou para um incremento de gozo. A este propósito, Lacan observa que, para Freud, a satisfação que acarreta a sublimação pode apresentar-se como satisfação da pulsão na medida mesma em que ela é inibida quanto à sua meta, ou seja, enquanto não alcança nenhum objetivo preciso, definitivo ou determinado. Resta, contudo, completa Lacan, que a sublimação não deixa de ser uma satisfação da pulsão, e isto sem que haja recalque (LACAN, 1973, p. 151).

4 In Deutsches Wörterbuch von Jacob Grimm und Wilhelm Grimm, zehnter Band, IV. Abteilung, Leipzig, Hirzel, 1942, art. Sublimieren. 
Nietzsche, a exemplo do que fará Freud mais tarde, recorre frequentemente a imagens que evocam o desvio da energia sexual para o domínio da criação artística, religiosa, cultural ou, em suma, para a esfera da linguagem. Assim, em Sobre verdade e mentira no sentido extra-moral, escrito em 1873, o instinto que impulsiona o homem a criar metáforas é tão fundamental e tão essencial para a existência que, ignorá-lo, equivaleria a ignorar o próprio homem. Tal instinto não se acha submetido à verdade; dificilmente dominável, ele é, no máximo, desviado para uma nova meta, cujas produções evanescentes, sob a forma de conceitos, permitem construir um novo mundo: um mundo regular, ordenado, firme, resistente e estável, cujo aspecto lembra o de um castelo ou de uma praça forte. Mas este instinto - embora Nietzsche não se refira explicitamente ao instinto sexual - pode igualmente extravasar-se através de outros meios. "Ele procura um novo território para sua atuação e um outro leito de rio, e o encontra no mito e, em geral, na arte" (VM).

Em Freud, a metáfora da via de escoamento já se acha presente nos Três ensaios sobre a teoria sexual (1905), onde ele se interroga sobre a gênese da obra de arte e sobre o processo civilizador em geral. A razão para isto, explica o inventor da psicanálise, reside nas próprias moções sexuais infantis, cujo afluxo continua agindo mesmo durante o período de latência e cuja energia sexual é integralmente, ou em parte, desviada para outros alvos (FREUD, 1999a, p. 78-79). Esta mesma metáfora recorrerá em Mal-estar na civilização (1930), onde retornará igualmente a questão do indivíduo e da nãosatisfação das pulsões que exige toda obra de civilização. De fato, aqui entram em jogo outras pulsões ou outras moções que deslocam, desviando-as e modificando-as, as condições necessárias para a sua satisfação. Neste sentido, acentua Freud, a sublimação das pulsões constitui um dos traços mais marcantes do desenvolvimento das civilizações; é ela efetivamente que permite às atividades científicas, artísticas e ideológicas representarem um papel tão proeminente na vida dos seres ditos civilizados (FREUD, 1999b, p. 457).

\section{Da sublimação sexual}

Como se pode observar, tanto em Freud quanto em Nietzsche, a sublimação remete, em última instância, às forças e à energia sexual do indivíduo que são desviadas, deslocadas, elevadas e transfiguradas em produtos que, aparentemente, nada têm a ver com a sexualidade. Já num esboço de inverno 1869-primavera 1870, em vista de um livro que, sintomaticamente, se intitularia 
Sócrates e o instinto, deparamos com uma subdivisão, onde se lê: "Conceito de amizade. Pulsão sexual idealizada" (KSA 7, p. 79). É no entanto em Miscelânea de opiniões e sentenças, publicado em 1879, que Nietzsche explicitamente associará a sublimação à sexualidade, assinalando-lhe portanto um dos significados que hoje ela possui. De resto, o aforismo 95 desta mesma obra, que tem precisamente por título Amor, se conclui nestes termos: "e todos aqueles, os inumeráveis, que sofrem de uma ausência de amor por parte de seus pais, de seus filhos ou de seus bem-amados; mas, principalmente, os seres de uma sexualidade sublimada encontraram no cristianismo o que lhes faltava."

Curiosamente, no primeiro parágrafo de Humano, demasiado humano (1878), Nietzsche se refere ao processo químico da sublimação para significar a volatilidade, a sutileza, a gradação e o caráter de inclusão que encerram todo sentimento e toda representação. Ele começa este texto desferindo um ataque contra os velhos preconceitos da concepção metafísica e popular, segundo os quais algo não pode originar-se de seu contrário, por exemplo, o racional do irracional, o sensível do inerte, o altruísmo do egoísmo, a verdade do erro, o lógico do ilógico. Para paliar essas dificuldades ou, mais exatamente, para esquivá-las, a metafísica - enfatiza o filósofo - negara até então a possibilidade de que um desses fenômenos pudesse engendrar o seu contrário. Antes, ela teria admitido, para as coisas consideradas superiores, uma origem nobre, divina e como que desencadeada direta e imediatamente da "coisa em si". Ora, para o autor de Humano, demasiado humano, não existe, a rigor, nem conduta altruística nem contemplação perfeitamente desinteressada, porquanto tanto uma quanto a outra não são senão "sublimações nas quais o elemento fundamental parece quase que volatilizado, revelando a sua presença somente à mais fina observação." Por conseguinte, conclui Nietzsche, tudo isso acarreta a necessidade de uma química das representações e dos sentimentos morais, religiosos, estéticos, como também das emoções existentes nas grandes e nas pequenas correntes da civilização atual.

Num texto escrito três anos depois (primavera-outono 1881), ele voltará a falar de uma sexualidade sublimada, mas atribuindo-a, desta vez, à concepção de Platão. Antes, porém, ele observa que quando uma impulsão se intelectualiza ela adquire, sob novas denominações, uma atração e uma sedução diferentes que lhe conferem, por assim dizer, uma estima e uma visão até então desconhecidas. É curioso, portanto, constatar que o filósofo associa a sublimação ao problema da linguagem e à nova perspectiva sob a qual ela passa a ser considerada. Não menos notável é vê-lo ajuntar, logo em seguida, que certas impulsões, como a impulsão sexual, são suscetíveis de um refinamento pelo 
intelecto, tais como o amor pela humanidade, a veneração por Maria e pelos santos, o entusiasmo, a exaltação artística, etc. O próprio Platão, conclui Nietzsche: "entende que o amor pelo conhecimento e pela filosofia seria uma impulsão sexual sublimada" (KSA 9, p. 496). ${ }^{5}$

Ocorre também a Nietzsche considerar a própria natureza como um fenômeno que exprime ou imita a atividade artística, porquanto as suas forças intervêm incessantemente no reino animal abraçando, também, as esferas do humano. Estas forças atestariam que, com o orgânico, começa igualmente o processo artístico. Mas não somente o mundo orgânico, o inorgânico também, através de suas transformações químicas, poderia ser a manifestação de uma tendência ou de uma impulsão artística, mimética, reprodutora (KSA 7, p. 437). Por conseguinte, a moral e a arte - enquanto meios pelos quais o sujeito transforma, transfigura e, de certo modo, se apropria da natureza - se revelam como fenômenos que se confundem, se penetram e se completam na própria dinâmica da sublimação: "A luta contra a 'sensualidade', através da virtude, é essencialmente de natureza estética” (KSA 7, p. 435).

Ora, se a sublimação em Nietzsche se manifesta também, a exemplo do que desenvolverá Freud mais tarde, como um processo de caráter sexual, e se ela se encontra agindo no seio da própria natureza, cabe agora perguntar pelo papel que representa a sublimação enquanto expressão das pulsões de destruição que, por sua vez, remetem ao conceito fundamental da vontade de potência.

\section{Da sublimação na e da crueldade}

A resposta a esta interrogação deve efetivamente ser buscada já no início da primeira fase e, mais precisamente, nos escritos trágicos, cujos textos fazem ressaltar a tendência à crueldade e ao aniquilamento como características próprias do período arcaico e dos tempos pré-homéricos. "Aqui, o nosso olhar mergulha nos abismos do ódio" (KSA 1, p. 784). E, de fato, esses primeiros escritos tratam de artistas, de guerreiros e conquistadores transbordantes de potência, de saúde, de volúpia e instinto de destruição.

5 Grifos do autor. - O texto de Platão ao qual Nietzsche faz alusão parece ser $O$ Banquete, 208a-212a. Num fragmento póstumo de fim 1886-primavera 1887, ele escreverá um longo texto intitulado: A vontade de verdade, onde trata igualmente da sublimação que se acha na visão artística, científica, moral e religiosa do mundo. KSA 12, p. 254-258. 
Assim, já no capítulo 3 de $O$ nascimento da tragédia surge a pulsão apolínea do belo que cria o mundo olímpico a partir de uma hierarquia titânica dos deuses do terror. Essa civilização apolínea começa, segundo Nietzsche, por desmoronar o reino dos titãs, por desbaratar a morada de seres gigantescos e edificar monumentos à sua própria vitória. Apolo, que é o deus escultor e, portanto, o deus da medida, da forma, da harmonia e da bela aparência pode também transmudar-se numa divindade terrível, plena de cólera e de malhumor. Certo, ele santifica e purifica o Estado: "Mas ele começa, como está indicado no início da Ilíada, por arremessar suas flechas contra os muares e os cães. Em seguida, fere os próprios homens, e por toda parte flamejam as fogueiras repletas de cadáveres" (KSA 7, p. 347). ${ }^{6}$ Como se pode ver, estes atributos parecem mais adaptar-se à figura de Dioniso, que é a divindade da destruição, da ebriedade, do êxtase e do frenesi, do que propriamente àquela do deus da luminosidade, das formas plásticas e da bela aparência. Convém no entanto relembrar que o apolíneo e o dionisíaco não podem ser pensados separadamente, porquanto eles se pertencem essencialmente, radicalmente, fundamentalmente: ora em luta aberta, ora reconciliadas, estas duas divindades não cessam porém de manifestar o gozo das forças procriadoras e destruidoras, a volúpia do eterno criar e do perpétuo aniquilar.

$\mathrm{Na}$ visão dos escritos trágicos, a civilização helênica foi edificada sobre um fundamento de violência e crueldade; donde o gozo experienciado na tragédia, nas competições e nos refinamentos da arte em geral. Esta questão, Nietzsche irá retomá-la em Para além de bem e mal, onde não somente a civilização grega, mas também quase tudo aquilo que se denomina "civilização superior" é visto como mergulhando suas raízes num fundo de crueldade que, no entanto, as máscaras, os disfarces e as metamorfoses das próprias forças que o constituem não param de espiritualizar, de elevar, de enobrecer e sublimar. Daí a veemência com que o filósofo completa a sua observação: "Esse 'animal feroz' não foi de modo algum abatido, ele vive, ele prospera, ele somente - se divinizou" (ABM 229).7 Assim, o que está à base da volúpia dolorosa que se exprime na tragédia é o instinto de crueldade; o que age agradavelmente, deleitosamente, na chamada "compaixão trágica" e em tudo aquilo que é sublime

6 Ao lermos esta passagem, não podemos senão quedar perplexos diante da afirmação de Giorgio Colli, um dos organizadores da edição crítica das Obras completas de Nietzsche, segundo a qual o filósofo jamais considerou os aspectos terríveis de Apolo. La nascita della filosofia, Milano, Adelphi, 1989, p. 18.

7 Veja também o parágrafo 230 da mesma obra. 
- que se trate dos enlevos e dos pruridos suscitados pela metafísica, do êxtase e do gozo que experimentam os cristãos diante da cruz -, todos estes fenômenos retiram a sua doçura, o seu mel, a sua sedução, daquele ingrediente de crueldade que neles se imiscui essencialmente, intrinsecamente (ABM 229). Daí também podermos melhor entender esta afirmação de um fragmento que se encontra isolado e sem relação direta com os outros textos que o circundam: "O refinamento da crueldade faz parte das fontes da arte" $^{\text {"KSA 11, p. 510) }}$

Sempre que aflora a questão do triunfo da civilização helênica, aflora simultaneamente aquela do desenvolvimento, do aperfeiçoamento e da purificação do mundo da arte. À interrogação que se coloca Nietzsche: "Como esta vontade terrivel é purificada e clarificada, isto é, dobrada e transformada em pulsões mais nobres?", ele próprio a responde afirmando que é por uma mudança no mundo da representação, ou "pelo grande afastamento de seu alvo, de sorte que uma tensão desmesurada a obriga a enobrecer-se" (KSA 7, p. 403). Enobrecendo-se, esta mesma vontade converter-se-á em gênio militar, em gênio político, em gênio artístico ou, em suma, em vontade de competição. Eis a razão pela qual o nascimento e a formação da cultura grega são concomitantes com aqueles da justa, do combate, da rivalidade ou, para usar o termo grego, do agón. Segundo Nietzsche, o agón se encontra presente nos pensamentos de Heráclito, de Platão, dos sofistas, assim como no desenvolvimento da educação e do Estado. Igualmente presente se faz ele sentir nos poemas de Homero e, também, "no symposion, na forma do diálogo espiritual" (KSA 8, p. 66).

Nesta mesma linha de reflexão, ao endereçar uma crítica à espera de um estado ideal da humanidade, Nietzsche afirma - antecipando várias análises que ressurgirão nos últimos escritos - que não se deve esperar do futuro da humanidade aquilo que, talvez, já fora engendrado em épocas passadas. Neste sentido, a soma de energia necessária às produções e ao florescimento do espírito se aproximaria mais do pretenso alvo da humanidade no meio de seu caminho do que no final. De sorte que o caudal impetuoso da vontade, que se quis desviar e converter em produções intelectuais, só pôde alcançar esta meta na medida mesma em que esta selvageria, ou este fluxo, fora submetido a uma cultura, a uma educação ou a uma disciplina intensa e rigorosamente seletiva (KSA 8, p. 92). Nestas condições, os torneios, os jogos, os certames e as competições em geral - que não são finalmente senão outras tantas maneiras de se negociar com as pulsões agressivas - se apresentavam como os espaços ideais em que a educação e a cultura podiam exercitar-se e desenvolver-se até atingirem o seu mais alto grau. 
Com efeito, na concepção nietzschiana, o espírito agonal está tão profundamente e tão radicalmente vinculado à cultura helênica, que não se pode conceber um sem o outro. Conseqüentemente, a justa se prestava como um elemento indispensável não somente à formação dos jovens aprendizes, mas também ao exercício regular de seus mestres. Por ela, a desconfiança recíproca, a inveja e a vontade de sobrepujar o inimigo se revelavam como verdadeiros estímulos a que os poetas apresentassem o produto de suas composições; por ela igualmente os sofistas, os retóricos e os filósofos - seus inimigos por excelência - não cessavam de se confrontar e de se superar mutuamente. Mesmo o drama - acentua Nietzsche -, que era considerado a forma mais geral da educação, não era oferecido ao povo senão sob as modalidades de uma luta homérica que travavam entre si os músicos, os dramaturgos e todos os outros grandes artistas. Mas - pondera o filósofo a notável produção estética e filosófica presente nos diálogos de Platão não pode ser compreendida, não pode ser pensada, não pode ser imaginada, senão como o resultado de uma competição com a arte dos retóricos, dos sofistas e dos dramaturgos de sua época (KSA 1, p. 790).

Se, no entanto, se retirar o certame da vida dos gregos, logo se fará sentir a sua contrapartida, isto é, o recalque e, poderíamos ajuntar, o retorno do recalque, porquanto não existe recalque sem o seu retorno. Nietzsche quer com isto significar que o universo pré-homérico, todo feito de crueldade, de ódio e prazer destruidor, pode a qualquer momento fazer irrupção e despedaçar o equilíbrio e a ilusão que suscita o mundo da arte. Eis a razão pela qual os escritos trágicos e, em particular, $O$ nascimento da tragédia, $O$ Estado grego e $A$ justa em Homero, pintam e representam a arte e a cultura em geral com uma variedade de cores e nuanças que deixam transparecer as gradações e inclusões do ódio e do amor, da construção e da destruição, da crueldade e da compaixão. É que esses próprios textos jogam com as sutilezas da arte que exprime as atrocidades desencadeadas pela cólera dos vencedores e dos conquistadores aguerridos do período arcaico da Grécia. De resto, a sublimação das pulsões de destruição confunde-se, ela também, com a arte enquanto jogo, ilusão, mentira, logro, engano ou ficção necessária. Num fragmento de verão 1872-início 1873, Nietzsche afirma com veemência: "Sem dúvida nós vivemos, dada a superficialidade do nosso intelecto, numa contínua ilusão: para vivermos, precisamos constantemente da arte" (KSA 7, p. 435). De modo que esta se apresenta, aos olhos do filósofo, como um meio pelo qual nós tornamos a existência suportável e, 
por isso mesmo, não cessamos de transformá-la, de justificá-la, de transfigurá-la e embelezá-la. Assim, o movimento instintivo que, na vida, cria as coisas terríveis e cruéis, na tragédia será capaz de transmudar-se em instinto de arte, de aparência, de ilusão, de ficção, de engano, de jogo e de gozo. A partir desta perspectiva, poderemos melhor entender as considerações que, dezesseis anos mais tarde, tecerá o discípulo de Dioniso em torno de sua obra inaugural, $O$ nascimento da tragédia. Ele declara, com efeito: "O nascimento da tragédia crê na arte com base numa outra crença: que não é possível viver com a verdade; que a 'vontade de verdade' já é um sintoma de degenerescência...” (KSA 13, p. 500).

Certo, nos primeiros escritos a arte é vista como ilusão, ficção e jogo enganador. À medida, porém, que se desenrola o pensamento nietzschiano, esta concepção atravessa variadas e imprevisíveis metamorfoses que a farão desembocar numa visão que é a repetição do mesmo na pluralidade, na multiplicidade e, portanto, na diferença e no vir-a-ser. Enriquecida pelas análises em torno da vontade de potência, a arte sobressai agora não somente como interpretação, mas também como força ou, mais exatamente, como expressão de forças e de relações de forças, como vontade de enganar e de ser enganado. Assim, a agressividade "inocente" que se manifestava entre os gregos por um excesso de seiva, de saúde e energia, a crueldade que procurava libertar-se extravasando-se para o mundo exterior serão doravante relidas, revaloradas e reinterpretadas a partir da vontade de potência, que é vontade de criação, de expansão, de apropriação, mas também - e paradoxalmente - de vingança, de autodestruição, de autoaniquilação, de morte, de nada.

\section{O ressentimento, a má consciência e o ideal ascético}

É bem verdade que as descobertas em torno do sadomasoquismo já se deixam perceber em vários textos de Humano, demasiado humano, como também em Aurora ${ }^{8}$ Elas retornarão igualmente na Gaia ciência, em Zaratustra e em Para além de bem e mal. É, no entanto, na Genealogia da moral que Nietzsche irá dedicar um estudo especial ao sadismo e ao masoquismo ao tratar, respectivamente, do ressentimento e da má consciência. De fato, assim como o rancoroso goza da visão do mal que inflige aos outros, assim também o homem

8 Veja, por exemplo: $H H, 103,104,141,142 ; \mathrm{A}, 18,68,113$. 
da má consciência frui do remorso e da dor que o torturam e o consumem lentamente. De igual modo, o artista, o filósofo e o sacerdote ascético gozam da força que consiste em desviar o curso dos instintos para reconduzi-los à paz definitiva, vale dizer, ao repouso dos repousos, ao sabá dos sabás ou, o que equivale ao mesmo, à morte, ao nada. Todavia - enfatiza Nietzsche - tanto o filósofo quanto o artista sabem também tirar proveito da sua "castidade", porquanto eles represam a energia das pulsões sexuais e a canalizam para a concepção e a gestação do pensamento e da obra de arte. É isto que, segundo o discípulo de Dioniso, Schopenhauer não soube entender. Pois, ele cria que um dos resultados da contemplação estética residiria na sua aptidão para agir contra o "interesse" sexual. Para Schopenhauer, portanto, a vantagem e utilidade do fato estético consistiriam em permitir que o indivíduo se libertasse da "vontade" na medida em que ele fosse capaz de domar, domesticar, abolir e negar esta mesma vontade. Por conseguinte, a volúpia se esvaeceria tão logo sobreviesse, em seu lugar, o gosto suscitado pela contemplação e pela apreciação da obra de arte (GM III 8).

Em Para além de bem e mal, obra que antecede e, de certa forma, preludia e prepara a Genealogia da moral, Nietzsche retoma, reavalia e aprofunda o que já havia desenvolvido, de maneira implícita ou explícita, nos escritos trágicos, a saber, a arte como um meio de transformar a energia das pulsões agressivas, desviando-a e assinalando-lhe um novo prazer ou, mais precisamente, um novo gozo, um novo deleite, uma nova fruição. Mas é não somente a obra de arte, é toda produção cultural que, finalmente, se revela como uma maneira de negociar com o instinto de crueldade, instinto que se exerce sobre os outros, no caso do ressentimento, ou que retorna contra o próprio sujeito, quando se trata da má consciência. Mais tarde, inspirado nos sexólogos Havelock Ellis e, principalmente, Krafft-Ebing, Freud designará estes dois fenômenos pelos nomes de sadismo e masoquismo. ${ }^{9}$ Convém no entanto relembrar que, tanto em Nietzsche quanto em Freud, estes dois processos nunca, ou quase nunca, agem de maneira isolada, visto que eles formam, por assim dizer, duas direções opostas de uma mesma dinâmica que manifesta uma tendência mais originária e mais primordial ainda. Trata-se, em última instância, das pulsões de destruição ou de morte, as quais caminham juntas, entrelaçando-se e incluindo-se radicalmente com as pulsões de vida

9 Para a ambígua relação de Freud com Nietzsche e as possíveis influências que este tivera sobre o inventor da psicanálise, veja o meu Freud, Nietzsche: l'énigme du père, in Freud et la philosophie, Le Portique, numéro 2, 2e. semestre, 1998. 
ou pulsões sexuais propriamente ditas. Em Nietzsche, o amálgama destes dois fenômenos se tornará ainda mais patente nas análises que se efetuarão em torno do ideal ascético, ou do sacerdote ascético, que compõe a Terceira Dissertação da Genealogia da moral. ${ }^{10}$ Resta, contudo, que este mesmo jogo de imbricação, de luta, de separação e re-inclusão que se desenrola no seio da vontade de potência é um leitmotiv que está sempre a retornar não somente na Genealogia da moral, mas, enfim, em toda a obra nietzschiana. É o que lemos, por exemplo, no parágrafo 225 de Para além de bem e mal:

Aquela tensão da alma na infelicidade, que faz crescer sua força, seu arrepio à vista do grande ir-ao-fundo, sua inventividade e bravura no carregar, agüentar, decifrar, utilizar a infelicidade, e tudo o que jamais lhe foi dado de profundeza, de segredo, de máscara, de espírito, de ardil, de grandeza: \% não lhe foi dado sob sofrimentos, sob a disciplina do grande sofrimento? No homem, criatura e criador estão unificados: no homem há matéria, fragmento, excedente, argila, lodo, insensatez, caos: mas no homem há também criador, formador, dureza de martelo, divindade de espectador e sétimo dia \% entendeis vós essa oposição? ${ }^{11}$

O criador é também um destruidor, eis o que Nietzsche não se cansa de repetir. Porque o homem do conhecimento e o artista que lhe é intrinsecamente aparentado não cessam de fazer violência à matéria resistente que eles próprios modelam, cinzelam, inscrevem, plasmam, transformam, transfiguram e embelezam. Ora, compelir o espírito a conhecer aquilo que a própria vontade procuraria evitar já manifesta um ato de intolerância e de violação contra si próprio. Trata-se, na sua ambiguidade fundamental, da vontade lutando contra si mesma a partir e através de um conflito insuperável de forças e de relações de forças ou, dito de outro modo, de construção e destruição, de ódio e amor, de alegria e aflição, de volúpia e dor, de prazer e desprazer. De angústia e gozo. Nesta perspectiva, o homem do conhecimento "se comporta como um artista e um transfigurador da crueldade", porquanto "o simples fato de estudar a fundo e seriamente um assunto é uma violação voluntária contra a tendência radical do espírito que, continuamente, se dirige para a aparência e a superfície: em toda vontade de conhecimento já se insinua uma gota de crueldade" (ABM 229).

10 Para a problemática do "entre-dois", ou do meio, que liga a vida e a morte, o ódio e o amor, a construção e a destruição na teoria e nos escritos de NIETZSCHE; Freud, veja o meu Eros e Tânatos: a vida, a morte, o desejo. São Paulo: Loyola, 2007. capítulo IV.

11 Tradução de R. R. Torres Filho. 
Este instinto de crueldade irá de novo emergir, com toda a sua veemência, naquelas forças niilistas do ressentimento que tiram prazer na vingança, na destruição, na negação, e que, paradoxalmente, acarretam a criação de novos valores, novos sentidos, novas significações e novas formas de existência. Por isso, não esqueçamos que a má consciência, que o filósofo considera como sendo a mais grave e a mais inquietante de todas as doenças, manifesta, ela também, as mesmas forças ativas que, nos conquistadores e nos artistas, edificam Estados, constroem civilizações, criam ou transformam religiões e, conseqüentemente, produzem um mundo mais rico, mais variado, mais refinado, mais diversificado. Mais deleitável. No entanto, a sua diferença principal consiste em que, no homem que sofre de si mesmo, a sua força permaneceu latente, mesquinha, retrógrada, porquanto ela não cria senão valores e ideais negativos que negam, denigram, condenam e culpabilizam a própria existência. Não obstante, este animal doente de si mesmo, que maquina, arquiteta, deprecia e renega os valores que ele próprio edificou, revela-se, no final, como a matéria sobre a qual se exerce a natureza plasmadora, instigadora e constrangedora desta mesma força. É o que Nietzsche afirma com insuperável ênfase na Genealogia da moral (II 18):

Esta secreta violação de si mesmo, esta crueldade de artista, este prazer em dar-se a si mesmo uma forma, como se faria com uma matéria difícil, recalcitrante e sofredora ao se marcar com o ferro de uma vontade, de uma crítica, de uma contradição, de um desprezo, de um não; este trabalho inquietante e terrivelmente voluptuoso de uma alma voluntariamente em desacordo consigo mesma, que sofre pelo prazer de fazer sofrer; toda esta 'má consciência' ativa, verdadeira matriz de fenômenos ideais e imaginários, terminou - já se adivinha - por produzir em plena luz uma profusão de afirmações, de novas e estranhas belezas, e talvez, pela primeira vez, a própria beleza...

Essas considerações que tece o discípulo de Dioniso em torno dos frutos, da autotortura e do gozo peculiares à má consciência não deixam de evocar um outro texto sobre os refinamentos da crueldade que se desenvolveram no seio do cristianismo. Neste sentido, a civilização ocidental é tributária do movimento cristão não somente por ele haver refinado, subtilizado e sublimado ao extremo as tendências típicas da destruição, mas também por ter-lhe permitido delas retirar o máximo de prazer ou, melhor, de gozo, de deleite, de volúpia, de fruição. No entanto, conclui Nietzsche: a espiritualização da crueldade, que se manifesta nas imagens e descrições que se fizeram do inferno, como também 
nas torturas, nas fogueiras da inquisição e nos autos-de-fé, representa, não obstante, um imenso progresso com relação à carnificina e aos espetáculos semiestúpidos que ofereciam as arenas romanas (KSA 11, p. 450).

Podemos pois deduzir que tanto nos seres fortes, plenos, potentes, violentos e agressivos, quanto naqueles em quem trabalham as forças niilistas da decadência - tais como os tipos do ressentimento, da má consciência e do ideal ascético - trata-se, afinal de contas, das mesmas pulsões de destruição e do mesmo instinto de liberdade e extravasamento que caracterizam a vontade de potência na sua ambivalência fundamental. É que todos estes seres gozam do sentimento de potência na medida mesma em que remodelam e retrabalham esta matéria resistente, recalcitrante e, ao mesmo tempo, transbordante de vontade e de desejo no seu vir-a-ser e no seu paradoxal tornar-se humano. Mesmo os esgotados, os depauperados, os debilitados e exauridos ainda querem, porquanto eles aspiram ao repouso final, à paz derradeira, ao sabá dos sabás. No fundo, esta espécie de ser revela tão-somente uma vontade: a paz do morto, cujo sorriso deleitado reflete a alegria serena do triunfo final. "Isto nada mais deseja; por isso ele age de maneira fria, repulsiva, superficial, sobre aquele que deseja" (KSA 7, p. 201). Por outro lado, os seres afirmativos, que transbordam de seiva, de saúde e vigor, encontram prazer tão-somente naquilo que oferece resistência e possibilidade de novas lutas, de novos combates, de novas superações, de novas transformações e repetições. O que eles almejam é, antes de tudo, a vitória, a adversidade sobrepujada e a conquista de horizontes mais vastos, mais incertos, mais desconhecidos e promissores de coisas enigmáticas, problemáticas, terríveis e belas.

Certo, nos textos do terceiro e último período, Nietzsche acentuará cada vez mais o paradoxo dos espíritos decadentes, no sentido em que eles criam a partir de seu próprio sofrimento e de sua própria doença. Que se trate, portanto, do tipo do ressentimento, cujo inimigo se situa fora do sujeito, ou daquele da má consciência, cuja agressividade se volta para o interior - ou ainda do ideal ascético, em quem ambos os tipos se entrelaçam de maneira íntima e radical -, os doentes se revelaram mestres na arte de refinar, subtilizar, espiritualizar ou, numa palavra, sublimar as pulsões de destruição. É aí onde eles encontram o seu gozo, a sua volúpia e deleitação máxima. Por outro lado - repita-se uma vez mais -, nesta última fase o filósofo retoma, revalorando-as e reinterpretando-as, as intuições que já havia desenvolvido nos "escritos trágicos", porquanto suas análises enfatizarão, com uma crescente intensidade, o papel representado pelos conquistadores e aristocratas do espírito, aqueles que, na visão nietzschiana, se mostram como os verdadeiros artistas da violência e da guerra. Estes, com efeito, 
possuem o instinto belicoso e agem por um excesso de saúde e de força agressiva que se derrama para fora e tira prazer ou, mais exatamente, gozo, de toda vitória, de todo aniquilamento e de toda crueldade. Foi, portanto, a partir e através de poderosas impulsões artísticas que a civilização helênica pôde canalizar sua energia destruidora para a justa, a competição, o certame e a criação do mundo olímpico dos deuses, onde o sofrimento - toda espécie de sofrimento - é igualmente transformado e transfigurado pela ilusão da bela aparência.

Se se seguir, pois o desenvolvimento da escrita nietzschiana - que se desdobra segundo uma incessante dinâmica de revaloração, releitura e reinterpretação - tornar-se-á mais claro por que os últimos textos insistem com tanta veemência sobre a crueldade voluptuosa que caracteriza essencialmente os homens fortes, saudáveis, potentes e intrinsecamente realizados. É que eles sabem, melhor, eles podem afirmar-se a si próprios por um sentimento de força acumulada e de júbilo mesmo com relação àquilo que faria tremer os fracos, os impotentes e radicalmente doentes. Por isso, o discípulo de Dioniso chega mesmo a detectar na predileção pelo incerto, o terrível e o duvidoso um sinal, ou um sintoma, de plenitude e de saúde elevada ao mais alto grau. Do mesmo modo, o gozo que se experiencia na tragédia torna-se a pedra de toque apta a distinguir as épocas e os seres excepcionalmente ricos e potentes. Em outros termos, os espíritos heroicos se aprovam a eles mesmos na crueldade trágica, no sentido em que se revelam bastante duros para experienciarem o sofrimento enquanto gozo e para retirarem de todo conflito e de toda resistência aquilo que confirma, reforça e faz crescer a sua potência e exuberância. Quanto ao artista trágico, sua profundidade e peculiaridade residem precisamente em que ele sabe abraçar as mais remotas consequências e aventurar-se pelos mais sinuosos, os mais incertos e imprevisíveis caminhos. Através da arte, "ele aprova a economia geral que justifica as coisas tremendas, perversas, problemáticas, e ele faz mais do que simplesmente... justificar" (KSA 12, p. 557). Ele as transforma, as embeleza, as transfigura, as sublima e nelas experiência gozo, deleite, fruição...

\section{Referências}

ALMEIDA, R. M. de. Eros e Tânatos: a vida, a morte, o desejo. São Paulo: Loyola, 2007. cap. IV.

FREUD, S. Drei Abhandlungen zur Sexualtheorie. In: FREUD, S. Gesammelte Werke (GW). Frankfurt am Main: Fischer Taschenbuch, 1999a. v. 5 e 18. 
Das Unbehagen in der Kultur. In: FREUD, S. Gesammelte Werke (GW). 1999b. v. 14 e 18.

LACAN, J. Le Séminaire, Livre XI, Les quatre concepts fondamentaux de la psychanalyse. Paris: Seuil, 1973.

NIETZSCHE, F. Obras incompletas. Tradução de Rubens Rodrigues Torres Filho. São Paulo: Abril Cultural, 1978. (Coleção Os Pensadores).

Sämtliche Werke: Kritische Studienausgabe (KSA). Berlin: New York: DTV, 1980. (Edição organizada por Giorgio Colli e Mazzino Montinari). NOVALIS, F. Blütenstaub. In: NOVALIS, F. Three works. Cambridge: Cambridge University Press, 1955.

SCHUTTE, O. Beyond Nihilism: Nietzsche without masks. Chicago: The University of Chicago Press, 1984. p. 207.

Recebido: 13/05/2008

Received: 05/13/2008

Aprovado: 22/06/2008

Approved: 06/22/2008 